\title{
Perencanaan Keperawatan dalam Asuhan Keperawatan
}

\author{
Eka Rosliani Nasution \\ ekaroslianinasution1303@gmail.com
}

\begin{abstract}
Abstrak
Mutu asuhan keperawatan sangat dipengaruhi oleh kualitas pelayanan kesehatan dan bahkan sering menjadi salah satu faktor penentu citra institusi palayanan di mata masyarakat. Untuk menilai kualitas pelayanan keperawatan diperlukan adanya standar praktik keperawatan yang merupakan pedoman bagi perawat dalam melaksanakan asuhan keperawatan yang diwujudkan dalam bentuk proses keperawatan baik dari pengkajian sampai evaluasi. Pengetahuan merupakan salah satu faktor yang erat kaitanya dengan efektifitas penerapan asuhan keperawatan.Peningkatan kualitas pelayanan mutlak perlu dilakukan oleh unit kesehatan rumah sakit dalam menghadapi era globalisasi. Salah satu upaya peningkatan kualitas pelayanan kesehatan adala dengan mengukur kepuasan pasien. Kepuasan pasien tergantung pada kualitas pelayanan yang diberikan. Suatu pelayanan dikatakan baik oleh pasien, jika jasa yang diberikan dapat memenuhi kebutuhan atau harapan pasien. Kurangnya kelengkapan pendokumentasian asuhan keperawatan (58\%) mempengaruhi pencapaian kualitas pelayanan kesehatan di rumah sakit. Melihat manfaat dan pentingnya pendokumentasian keperawatan maka perlu adanya kontrol terhadap pendokumentasian asuhan keperawatan yang dilakukan perawat yaitu dengan adanya kegiatan supervisi.Discharge planning merupakan suatu bentuk perilaku perawat dalam pelayanan keperawatan. Sering dijumpai pelaksanaan discharge planning hanya diberikan pada saat pasien akan pulang dari rumah sakit.
\end{abstract}

\section{PENDAHULUAN}

\section{Latar Belakang}

Keperawatan adalah salah satu profesi pelaku pemberi pelayanan kesehatan, memiliki peranan penting dalam menentukan keberhasilan kesehatan secara keseluruhan. Pelayanan keperawatan merupakan pelayanan profesional sebagai bagian integral dari pelayanan kesehatan yang didasarkan ilmu dan kiat keperawatan (Nursalam, 2008). Rumah Sakit mengupayakan tercapainya enam sasaran keselamatan pasien yang salah satunya yaitu pe-ngurangan resiko infeksi terkait pelaya-nan. Resiko infeksi merupakan salah satu penyebab rendahnya kualitas mutu pelayanan kesehatan di Rumah Sakit (Kemenkes, 2013). Pelayanan kesehatan merupakan bentuk jasa yang diberikan oleh organisasi penyedia layanan kesehatan. Salah satu bentuk layanan kesehatan di organisasi penyedia layanan kesehatan adalah pelayanan keperawatan.

Mutu pelayanan keperawatan sebagai indikator kualitas pelayanan kesehatan menjadi salah satu faktor penentu citra institusi pelayanan kesehatan di mata masyarakat. Hal ini terjadi karena keperawatan merupakan kelompok profesi dengan jumlah terbanyak, paling depan dan terdekat dengan penderita, kesakitan, serta kesengsaraan yang dialami pasien dan keluarganya. Salah satu indikator dari mutu pelayanan keperawatan itu adalah apakah pelayanan keperawatan yang diberikan itu memuaskan atau tidak. Pasien sebagai pengguna jasa pelayanan keperawatan menuntut pelayanan keperawatan yang sesuai dengan haknya, yakni pelayanan keperawatan yang bermutu dan paripurna. Pasien akan mengeluh bila perilaku caring yang dirasakan tidak memberikan nilai kepuasan bagi dirinya (Asmuji, 2012). 
Mutu asuhan keperawatan sangat dipengaruhi oleh kualitas pelayanan kesehatan dan bahkan sering menjadi salah satu faktor penentu citra institusi palayanan di mata masyarakat. Untuk menilai kualitas pelayanan keperawatan diperlukan adanya standar praktik keperawatan yang merupakan pedoman bagi perawat dalam melaksanakan asuhan keperawatan yang diwujudkan dalam bentuk proses keperawatan baik dari pengkajian sampai evaluasi (Nursalam, 2008). Dimensi mutu pelayanan kesehatan antara lain: yang pertama Reliabillity (Kehandalan) dimensi yang mengukur kehandalan dar perusahaan dalam memberikan pelayanan kepada pelanggannya, yang kedua Responsiveness (Cepat tanggap) harapan pelanggan terhadap kecepatan pelayanan hampir dapat dipastikan akan berubah dengan kecenderungan naik dari waktu ke waktu, yang ketiga Assurnce (Jaminan) jaminan mencakup kemampuan, kesopanan, dan sifat dapat dipercaya yang dimiliki para staf, bebas dari bahaya, risiko atau keraguan, yang keempat Empathy (Perhatian) setelah kebutuhan fisik, keamanan, dan sosial terpenuhi maka dua kebutuhan lagi akan dikejar oleh manusia yaitu kebutuhan ego dan aktualisasi dan yang kelima Tangible (Fasilitas yang memadai) pelanggan akan menggunakan indra penglihatan untuk menilai suatu kualitas pelayanan, meliputi faslitas fisik, perlengkapan, pegawai, dan sarana komunikasi (Muninjaya, 2014).

Rumah sakit merupakan salah satu sistem pemberian pelayanan kesehatan, dimana dalam memberikan pelayanan menggunakan konsep multidisiplin. Kolaborasi multidisiplin yang baik antara medis, perawat, gizi, fisioterapi, farmasi, dan penunjang diharapkan mampu memberikan pelayanan terbaik kepada masyarakat (Hariyati, 2008). Salah satu bentuk pelayanan kesehatan itu sendiri adalah pelayanan keperawatan profesional dimana salah satunya adalah perencanaan pulang. Perencanaan pulang keperawatan merupakan komponen yang terkait dengan rentang keperawatan dari pasien masuk rumah sakit hingga kepulangannya. Perencanaan pulang dilaksanakan selama dalam perawatan dan evaluasi pada saat pasien dipersiapkan untuk pulang, dengan mengkaji kemungkinan rujukan atau perawatan lanjut di rumah sesuai kebutuhan (Keperawatan, 2011). Perencanaan pulang ini akan memberikan proses deep- learning pada pasien hingga terjadinya perubahan perilaku pasien dan keluarganya dalam memaknai kondisi kesehatannya (Pemila, 2011). Kegagalan untuk memberikan dan mendokumentasikan perencanaan pulang akan beresiko terhadap beratnya penyakit, ancaman hidup, dan disfungsi fisik (Nursalam, 2009). Perencanaan pulang dapat mengurangi hari/lama perawatan pasien, mencegah kekambuhan, meningkatkan kondisi kesehatan pasien, menurunkan beban keluarga pasien, dan menurunkan angka mortalitas dan morbiditas (Pemila, 2011). Pelaksanaan perencanaan pulang yang baik akan berpengaruh terhadap peningkatan kualitas kesehatan pasien.

Pelaksanaan perencanaan pulang tidak terlepas dari tangan para perawat. Perawat bertanggung jawab dalam segala bentuk pelayanan keperawatan kepada pasien. Berdasarkan hal ini, perawat mempunyai peran penting dalam perencanaan pulang pasien, dimana pelaksanaannya memerlukan komunikasi yang baik dan terarah sehingga apa yang disampaikan dapat dimengerti dan berguna untuk proses perawatan dirumah (Nursalam, 2009). Pelaksanaan perencanaan pulang tersebut mencakup perencanaan pulang, persiapan sebelum hari pemulangan klien, dan pada hari pemulangan klien (Potter \& Perry, 2005). Discharge planning merupakan bagian dari proses keperawatan dan fungsi utama dari perawatan. Discharge planning harus dilaksanakan oleh perawat secara terstruktur dimulai dari pengkajian saat pasien masuk ke rumah sakit sampai pasien pulang (Potter \& Perry, 2010). Pelaksanaan discharge planning, sebagian besar belum dilaksanakan oleh perawat di rumah sakit. Kendatipun dilakukan, belum dilaksanakan sesuai dengan standar dan prosedur pelaksanaan. Kurangnya pemahaman tentang mekanisme pelaksanaan discharge planning dan tingginya beban kerja menyebabkan perawat cenderung tidak melakukan discharge planning kepada pasien (Zees, 2010).

\section{Metode}

Penelitian ini dibagi menjadi dua tahap yaitu tahap pertama adalah penelitian deskriptif observasional dengan pendekatan survei yang menggambarkan pelaksanaan discharge planning, dimana peneliti mengidentifikasi pelaksanaan discharge planning dan faktor- faktor yang 
mempengaruhi pelaksanaan discharge planning, serta kesesuaiannya menurut Standar Operasional Prosedur (SOP) yang berlaku, kajian teori dan konsep serta hasil penelitian. Pada tahap kedua adalah penelitian eksperimen yang bertujuan mengembangkan dan menguji coba model discharge planning terintegrasi.

\section{Hasil}

Menurut telaah hasil penelitian, peneliti asumsi bahwa kinerja perawat masih rendah disebabkan kurangnya motivasi perawat dalam bekerja dimana kinerja perawat dalam memberikan asuhan keperawatan, menentukan diagnosa keperawatan dan memodifikasi rencana asuhan keperawatan masih kurang, respon perawat dalam menanggapi dan memberikan pelayanan kepada pasien kurang. Selain itu, perawat juga kurang memberikan motivasi dengan berbagi informasi dan berkonsultasi dengan pasien, perawat jarang mengikuti pelatihan - pelatihan serta perawat kurang mampu menggali masalah pasien yang belum terkaji dikarenakan masih banyaknya perawat yang dalam pekerjaannya masih dan harus menunggu instruksi profesi lain dalam perawatan pasien sehingga dapat mempengaruhi kebebasan perawat untuk pengambilan keputusan tentang perawatan pasien.

Kelengkapan dokumentasi asuhan keperawatan yang dilakukan oleh perawat dikarenakan adanya kontrol dan pengawasan dari kepala ruangan terhadap dokumentasi asuhan keperawatan yang dilakukan oleh perawat dengan adanya kegiatan supervisi. Kegiatan supervisi yang dilakukan dapat membantu perawat dalam pendokumentasian asuhan keperawatan, supervisi yang dilakukan secara berulang dapat mengurangi kesalahan perawat dalam melakukan pendokumentasian dan supervisi yang dilakukan dengan baik akan meningkatkan pendokumentasian asuhan keperawatan.

\section{Pembahasan}

Keperawatan adalah suatu profesi yang meng- abdi kepada manusia dan kemanusiaan, mendahulu- kan kepentingan kesehatan klien diatas kepentingan- nya sendiri, suatu bentuk pelayanan/asuhan yang bersifat humanistik, menggunakan pendekatan holis- tik, dilaksanakan berdasarkan ilmu dan kiat kepera- watan, serta menggunakan kode etik keperawatan sebagai tuntunan utama dalam melaksanakan pelayanan/asuhan keperawatan (Aini, 2018).

Sesuai dengan ciri-ciri profesi maka harus dise- lenggarakan pendidikan profesional. Oleh karena itu, mahasiswa harus menempuh 2 jenjang pendidik- an yaitu Akademik dan Profesi Ners. Tahap akade- mik adalah program pendidikan untuk mencapai kemampuan keilmuan keperawatan dan diberi gelar Sarjana Keperawatan (S.Kep) dilanjutkan dengan tahap profesi melalui program pendidikan untuk mencapat kompetensi perawat dan diberi gelar Ners.

Perawat sebagai salah satu faktor yang mempengaruhi kualitas asuhan keperawatan dan merupakan faktor yang paling menentukan untuk tercapainya pelayanan kesehatan yang optimal dengan asuhan keperawatan yang bermutu. Untuk dapat melaksanakan asuhan keperawatan dengan baik seorang perawat perlu memiliki kemampuan berhubungan dengan klien dan keluarga, serta berkomunikasi dengan anggota tim kesehatan lain, mengkaji kondisi kesehatan klien baik melalui wawancara, pemeriksaan fisik maupun menginterprestasikan hasil pemeriksaan penunjang, menetapkan diagnosis keperawatan dan memberikan tindakan yang dibutuhkan klien, mengevaluasi tindakan keperawatan yang telah diberikan serta menyesuaikan kembali perencanaan yang telah dibuat dan sebagainya (Copel, 2007).

Setiap orang akan menilai mutu layanan kesehatan berdasarkan standar atau karakteristik atau kriteria yang berbeda-beda. Salah satu kesulitan dalam merumuskan pengertian mutu layanan kesehatan adalah karena mutu layanan kesehatan itu sangat melekat dengan faktor-faktor subjektivitas orang yang berkepentingan, baik pasien atau konsumen, pemberi layanan kesehatan 
(provider), penyandang dana, masyarakat ataupun sarana layanan kesehatan. Pandangan pasien atau masyarakat ini sangat penting karena pasien yang merasa puas akan mematuhi pengobatan dan mau datang berobat kembali. Dimensi mutu layanan kesehatan yang berhubungan dengan kepuasaan pasien dapat memengaruhi keseharian masyarakat dan kesejahteraan masyarakat (Imbalo S. Pohan 2014).

Kepuasan pasien dalam menilai pelayanan baik dan merupakan pengukuran penting yang mendasar bagi mutu pelayanan. Hal ini karena memberikan informasi terhadap suksesnya pemberian pelayanan berkualitas dengan nilai dan harapan pasien yang mempunyai wewenang sendiri untuk menetapkan standar mutu pelayanan yang dikehendaki.Setiap mereka yang terlihat dalam layanan kesehatan, seperti pasien, masyarakat dan organisasi masyarakat, profesi layanan kesehatan, dinas kesehatan dan pemerintah daerah pasti mempunyai pandangan yang berbeda tentang unsur apa yang penting dalam mutu layanan kesehatan. Perbedaan perspektif tersebut antara lain disebabkan pleh terdapatnya perbedaan dalam latar belakang, pendidikan, pengetahuan, pekerjaan, pengalaman, lingkungan dan kepentingan.

Lima kelompok karakteristik yang digunakan dalam mengevaluasi kualitas jasa pelayanan yang mengacu pada lima dimensi pelayanan untuk mewujudkan kepuasaan yaitu reliability (keandalan), assurance (jaminan), tangible (kenyataan), responsiveness (ketanggapan). Kelima hal tersebut memegang peran penting dalam industri jasa pelayanan kesehatan sebuah rumah sakit. Pasien akan merasa puas jika pasien memperoleh pelayanan yang baik terjadap kinerja perawat atau dengan yang diharapkannya (Muninjaya, 2013).

Menurut teori hakikat dokumentasi asuhan keperawatan adalah terciptanya kegiatankegiatan keperawatan yang menjamin tumbuhnya pandangan, sikap, cara berpikir, dan bertindak profesional pada setiap perawat. Pendekatan yang sistematis dan logis dengan landasan ilmiah yang benar, serta melalui dokumentasi proses keperawatan, semuakegiatan dalam proses keperawatan dapat ditampilkan kembali sehingga dapat diteliti ulang untuk dikembangkan atau diperbaiki (Nursalam, 2014).

Alasan mengapa perawat jarang untuk melengkapi dokumentasi asuhan keperawatan salah satu faktornya karena kurangnya pengawasan, pengontrolan terhadap dokumentasi asuhan keperawatan. Perawat merasa dokumentasi asuhankeperawatan terlalu banyak, tidak ada hubunganya dengan gaji serta kurangnya teguran dari atasan.Jumlah perawat ruangan yang sangat sedikit dengan kapasitas pasien dan beban kerja yang sangat banyak membuat perawat jarang menuliskan dokumentasi asuhan keperawatan secara lengkap, perawat biasanya hanya menuliskan nama pasien tanpa nomor RM, tidak melengkapi data pemeriksaan fisik pasien, tidak menuliskan analisa data, tujuan dan rencana tindakan, pada lembar implementasi perawat sering tidak menuliskan, evaluasi perawat sering tidak menuliskan catatan perkembangan pasien dan tidak mencantumkan paraf (Lestari, 2014).

Selain itu penelitian ini diperkuat oleh penelitian terdahulu yang dilakukan oleh Yanti (2013). Kelengkapan dokumentasi proses asuhan keperawatan dalam kategori kurang baik adalah sebesar 54,7\%. Penyebab dari kurang baiknya dokumentasi asuhan keperawatan yang dilakukan adalah karenamasih kurangnya pengetahuan dan pemahaman dari perawat, perawat lebih memprioritaskan tindakan langsung dari pada dokumentasi, serta kekurangan tenaga keperawatan. Pada tahap pengkajian menunjukkan bahwa sebagian besar responden mencatat data hasil pengkajian sesuai dengan pedoman.

Kualitas pelayanan ditentukan oleh manajemen asuhan keperawatan. Pelaksanakan asuhan keperawatan dengan menggunakan metode proses keperawatan untuk menyelesaikan masalah pasien, antara pasien dan perawat berhubungan secara langsung dalam pengelolaan asuhan keperawatan (Muhlisin, 2008) .Dokumentasi keperawatan merupakan aspek penting yang perlu ditingkatkan. Dokumentasi keperawatan menjadi salah satu fungsi yang paling penting dari perawat sejak zaman Florence Nightingale, sistem pelayanan kesehatan mengharuskan adanya pendokumentasian karena dapat menjamin kelangsungan perawatan, dapat berfungsi sebagai bukti 
hukum dari proses perawatan dan mendukung evaluasi kualitas perawatan pasien, perawat yang kurang patuh dalam pendokumentasi asuhan keperawatan akan berakibat pada rendahnya mutu kelengkapan dokumentasi asuhan keperawatan.

Putra, Prabowo, \& Setiawan (2013) menyebutkan bahwa model praktek keperawatan profesional memberikan dampak positif terhadap kepuasan pasien, keluarga, dan perawat, selain itu model praktek keperawatan profesional juga berdampak terhadap kepuasan kerja profesi lain, dalam penelitian ini adalah dokter yang menyimpulkan bahwa dokter lebih puas bekerjasama dengan perawat pada model praktek keperawatan profesional.

Nursalam (2011) mengatakan bahwa dalam pengembangan model asuhan keperawatan profesional ada tiga aspek yang perlu dikembangkan yaitu ketenagaan, sistem pemberian asuhan keperawatan, dan dokumentasi keperawatan. Pengembangan model asuhan keperawatan profesional metode tim dimaksudkan untuk menjawab tantangan terhadap kualitas pelayanan dan asuhan keperawatan perawat yang dirasakan belum memuaskan. Menurut Wahyuni (2007) kinerja perawat dalam mengimplementasikan model praktek keperawatan profesional dipengaruhi oleh kompetensi kepala ruang dalam pelaksanaan standar manajemen pelayanan keperawatan.

Dokumentasi keperawatan dalam bentuk dokumen asuhan keperawatan merupakan salah satu alat pembuktian atas perbuatan perawat selama menjalankan tugas pelayanan keperawatan. Sehingga dokumentasi asuhan keperawatan menjadi hal yang penting sebagai alat bukti tanggung jawab dan tanggung gugat dari perawat dalam menjalankan tugasnya. Perawat profesional dihadapkan pada suatu tuntutan tanggung jawab yang lebih tinggi dan tanggung gugat setiap tindakan yang dilaksanakan, artinya intervensi keperawatan yang diberikan kepada klien harus dihindari terjadinya kesalahan-kesalahan dengan pendekatan proses keperawatan dan pendokumentasian asuhan keperawatan yang akurat dan benar (Nursalam 2009).

Menurut Anjaryani (2009) mengemukakan bahwa mutu asuhan keperawatan sangat mempengaruhi kualitas pelayanan kesehatan dan menjadi salah satu faktor penentu citra institusi pelayanan di mata masyarakat, kualitas pelayanan keperawatan juga akan meningkatkan kepuasan pasien (Trimumpuni, 2009). Untuk mempertahankan dan meningkatkan kualitas asuhan keperawatan diperlukan alat ukur yaitu standar asuhan keperawatan yang baku dan disyahkan melalui kesepakatan oleh tenaga perawat. Salah satu usaha untuk memberikan pelayanan yang berkualitas dan profesional tersebut adalah pengembangan model asuhan keperawatan profesional metode tim yang memungkinkan perawat profesional mengatur dalam pemberian asuhan keperawatan termasuk lingkungan untuk menopang pemberian asuhan tersebut.

\section{PENUTUP}

Perencanaan keperawatan yang dipersiapkan oleh perawat harus berhubungan dengan kondisi pasien berdasarkan pengkajian dan diagnose keperawatan. Perencanaan keperawatan menjadi dasar perawat dalam mengimplementasikan tindakan yang akan dilakukan. Beberapa hal yang perlu diperhatikan dalam perenacanan keperawatan seperti menentukan prioritas masalah, menentukan tujuan dan kriteria hasil yang diharapkan, merumuskan rencana tindakan keperawatan dan rasional rencana tindakan keperawatan. Perencanaan keperawatan merupak bagian dari proses keperawatan yang bermanfaat dalam pelayanan dan asuhan yang akan diberikan perawat kepada pasien.

\section{Daftar Pustaka}

Achmadi, L. D. (2015, Agustus). Gambaran Tingkat Pengetahuan Perawat dalam Penerapan Standar Asuhan Keperawatan di Ruang Rawat Inap Interna RSUP Datoe Bhinangkang. e-journal Keperawatan, 3. 
Agustin, R. (2017). Optimalisasi Pelaksanaan Discharge Planning melelui Pengembangan Model Discharge Planning Terintegrasi Pelayanan Keperawatan. Jurnal Keperawatan Muhammadiyah, 2, 91-99.

Aini, D. N. (2018). Hubungan Kualitas Pelayanan Keperawatan dengan Tingkat Kepuasan Pasien Rawat Inap di RSUD DR. H. SOEWONDO KENDAL. Jurnal Ners Widya Husada Semarang , 2.

Aini, N. (2018). Model Keperawatan beserta aplikasinya dalam keperawatan. Malang: Universitas Muhammadiyah Malang

Bandiyah, S. (2017). Ketrampilan Dasar Keperawatan. Yogyakarta. Nuha Medika

Butar-Butar, J., \& Simamora, R. H. (2016). Hubungan Mutu Pelayanan Keperawatan dengan Tingkat Kepuasan Pasien Rawat Inap di RSUD Pandan Kabupaten Tapanuli Tengah. Jurnal Ners Indonesia,6(1), 50-63.

Hasbi, F. H. (2012). Analisis Hubungan Persepsi Pasien tentang Mutu Pelayanan dengan Pemanfaatan Ulang Pelayanan Rawat Jalan Puskesmas Poncol Kota Semarang. Jurnal Kesehatan Masyarakat Universitas Diponegoro, 1.

Kasim, M., \& Abduroof, M. (2016, Mei). Peningakatan Kualitas Pelayanan dan Pendokumentasian Asuhan Keperawataqn dengan Metode TIM. Nurseline Journal, 1, 62-72.

Purnamasari, L. D., \& Ropyanto, C. B. (2012). Evaluasi Pelaksanaan Perencanaan Pulang. Jurnal Keperawatan Diponegoro, 1, 213-218.

Rezkiki, F., \& Ilfa, A. (2018). Pengaruh Supervisi Terhadap Kelengkapan Dokumentasi Asuhan Keperawatan Di Ruangan Non Bedah. Real in Nursing Journal, 1(2), 67-76.

Siahaan, J. V., Siagian, A., \& Bukit, E. K. (2018). Pengaruh pelatihan ronde keperawatan terhadap kinerja perawat dalam asuhan keperawatan di rs royal prima medan. Jumantik (Jurnal Ilmiah Penelitian Kesehatan), 3(1), 1-15.

Simamora, R. H. (2005).Hubungan Persepsi Perawat Pelaksana Terhadap Penerapan Fungsi Pengorganisasian Yang Dilakukan Oleh Kepala Ruangan Dengan Kinerjanya Diruang Rawat Inap RSUD Koja Jakarta Utara(Doctoral dissertation, Tesis FIK UI, Tidak dipublikasikan). 